CZASOPISMO INŻYNIERII LACDOWEJ, ŚRODOWISKA I ARCHITEKTURY JOURNAL OF CIVIL ENGINEERING, ENVIRONMENT AND ARCHITECTURE

JCEEA, t. XXXI, z. 61 (1/14), styczeń-marzec 2014, s. 5-21

Jacek ABRAMCZYK ${ }^{1}$

\title{
PRINCIPLES OF GEOMETRICAL SHAPING EFFECTIVE SHELL STRUCTURES FORMS
}

\begin{abstract}
The paper concerns geometrical shaping of shell structures composed of individual shells arranged effectively in space that is in a way similar to properties of a regular, geometrical surface with taking into account straight lines and planes normal to the base surface. The individual segments are made up of unidirectional folded flat sheets transformed into shell shapes. A freedom of transversal width increments of these sheets is assured while transforming, which ensures their possible small effort - such a deformation of a material intended for transferring functional loads but which makes restrictions concerning the shell sheets shapes. These shape restrictions are provoked by the strictly determined stiffness characteristics of the shell sheets and cause of the edge or discontinuous areas between adjacent shells segments in the shell structure. The method of delimiting great diversity of effective, compound shell forms whose general shapes are close to regular, geometrical surfaces characterized by any sign of the Gaussian curvature is presented. Innovation of the way also consists in integration of the form of a whole building object (walls and shell roof). It is achieved by division of the elevation walls into flat areas contained in planes close to planes normal to the base surface as accurate as possible. The segment's directrices are also contained in these planes. The presented issues are the ground for elaborating a method of shaping of the light gauge steel shell structures and their further integration with whole building objects.
\end{abstract}

Keywords: light gauge steel shell structures, free deformation, folded sheets

\section{Shell structures made of freely deformed flat folded sheets}

The paper focuses on a geometrical way of arranging individual light gauge shells in the three-dimensional space compatible with any kind of a base surface to get a compound shell [1,2], which is said to be a shell structure. The individual shells of the compound shell are called stripes or segments.

To obtain a general form of the shell structure, we should accepted the regular base surface [3]. The models of two shell structures based on a base plane and a base ellipsoid are depicted in Figs. 1, 2.

\footnotetext{
${ }^{1}$ Jacek Abramczyk, Rzeszow University of Technology, 12 Poznanska St., 35-959 Rzeszow, +17 8651307, e-mail: jacabram@pry.edu.pl
} 

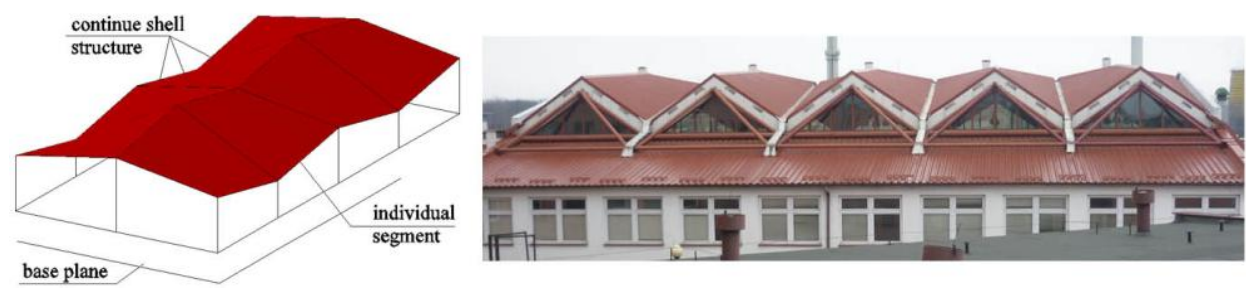

Fig. 1. The model and view of two shell structures created with horizontal and oblique base planes Rys. 1. Model i widok dwóch struktur powłokowych opartych na płaszczyznach bazowych: poziomej i ukośnej

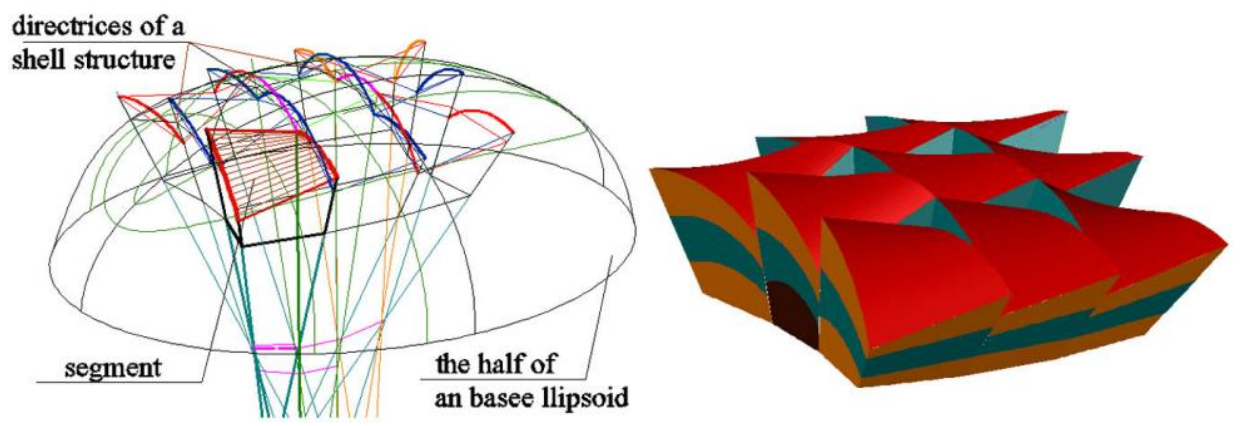

Fig. 2. The concept and visualization of a discontinuous shell structure with a base ellipsoid

Rys. 2. Koncepcja i wizualizacja nieciagłej struktury powłokowej zbudowanej na podstawie elipsoidy bazowej

The segments are made up of flat unidirectional folded sheets connected one to another by their longitudinal edges and transformed to spatial shapes as a result of assembling them to shell directrices [4]. While transforming, a freedom of transversal width increments of each fold is assured to get their possible small efford, so the sheets (folds) are undergone initial free deformations called free deformations $[5,6]$.

From geometrical and physical properties of the freely deformed flat sheets it results their orthotropy, which causes that the accurate determination of directions and an arrangement of shell fold axes along each shell's directrix is required while creating models of each shell fold characterized by its small effort $[6,7]$. Each fold axis stays rectilinear and its neutral surface is also rectilinear while transforming [8]. Thus, a sector of a ruled surface is the model of each shell fold $[8,9]$. It exists interdependence between the lengths of two lines supporting the transversal opposite edges of the shell fold and its supporting conditions including curvatures and mutual positions of the segment directrices.

Additionally, from the fact that the freedom of the transversal width increments of all shell folds is assured it results the following restrictions: a) the biggest width of each shell fold is at its crosswise ends, b) the biggest shell fold's 
contraction is in the half of its lengths, c) the neutral surface of each shell fold is the central sector of a ruled surface so that its line of striction passes through the middle on the fold length $[6,8]$.

From the above restrictions of the shell fold shape it results the fact that they appear rectilinear / curvilinear edges or flat / shell areas between every pair of the adjacent segments of the shell structure disturbing smoothness or continuity of the structure $[5,6]$.

\section{Basic assumptions for shaping shell structures}

A geometrical model of each individual shell segment is fixed by means of its two directrices. The equations of these directrices in the same coordinate system are necessary to calculate the crosswise increments of the folds widths, the arrangement of points of assembling the folds ends along these directrices, and the arrangement of rulings modeling fold's axes in accurate way. This edge model is formed with a finite number of the rulings of a ruled surface $\sigma[6,7]$.

With respect to the restrictions referring to the shape changes of the folds while assembling them to the shell directrices it was decided that the activities provided by the method algorithm have to be done in two essential stages.

The first stage is produced by the action leading to creating a polyhedral structure called a controlling structure whose planes separate the individual segments of the shell structure from each other. The controlling structure delimits "cells" in the space, in which the segments satisfying the restrictions connected to the unidirectional folded sheeting are created.

The base ellipsoid enables us to delimit a controlling structure (see Fig. 3). The way recommends the effective covering of the base surface by segments so that the side edges and planes of the controlling structure, being sought, would be normal to the base surface $\sigma$ or close to those. Four adjacent planes of the controlling structure form one controlling composition $\Gamma_{i, j}$.

Four proper straight lines $n_{p i j}$ normal to the ellipsoid $\sigma$ do not intersect each other and they cannot create the side edges of the controlling composition (see Fig. 3). To obtain one „,ell”, 8 planes determined by straight lines tangent and normal to the base surface at the points $P_{11}, P_{12}, P_{21}, P_{22}$, have to be replaced with the system of four planes $\xi_{u 1}, \xi_{u 2}, \xi_{v 1}, \xi_{v 2}$ (see Fig. 4) from which each one: a) passes through one of the pairs $\left(P_{11}, P_{12}\right),\left(P_{21}, P_{22}\right),\left(P_{11}, P_{21}\right),\left(P_{21}, P_{22}\right)$, b) is parallel to one from among the edges $k_{u 1}, k_{v 1}, k_{u 2}, k_{v 2}$ common for each pair of the adjacent planes belonging to the above 8 planes normal to $\sigma$.

Thus, the four straight lines and four planes (see Fig. 4) being close to planes and planes normal to this ellipsoid form trapezoidal controlling compositions. These straight lines pass through the points of the intersection of the chosen lines $t_{i}, w_{j}$ of curvature on this ellipsoid $\sigma$ (Fig. 3, 4). 
The lines: $a_{11}, b_{11}, c_{11}, d_{11}$ of intersection of two adjacent planes of the same controlling composition are called the side edges but the lines: $u_{11}, v_{11}$ of intersection of two opposite planes of the same controlling composition are called the axes (Fig. 4). The faces of the controlling structure intersect the base surface in lines, which divide this surface into quadrilateral areas $\sigma_{i, j}$ arranged regularly on the base surface. In the second stage the segments $\Omega_{i, j}$ of a shell structure are assigned to these areas $\sigma_{i, j}$. According to the way the corner points of their border line are accepted or calculated on the side edges in proper distances from the base surface.

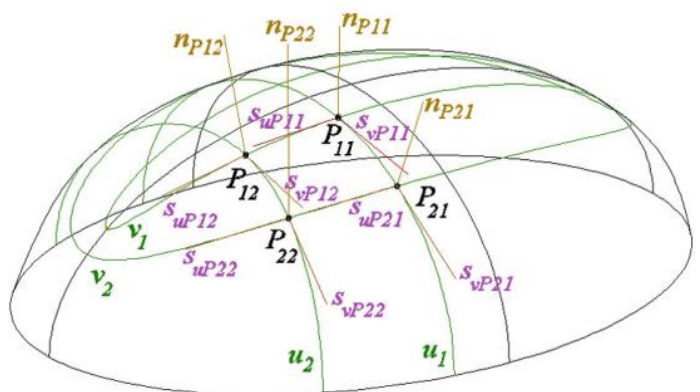

Fig. 3. The concept of a way of accepting the initial assumptions for designing shell structures

Rys. 3. Koncepcja sposobu przyjmowania założeń do projektowania struktury powłokowej
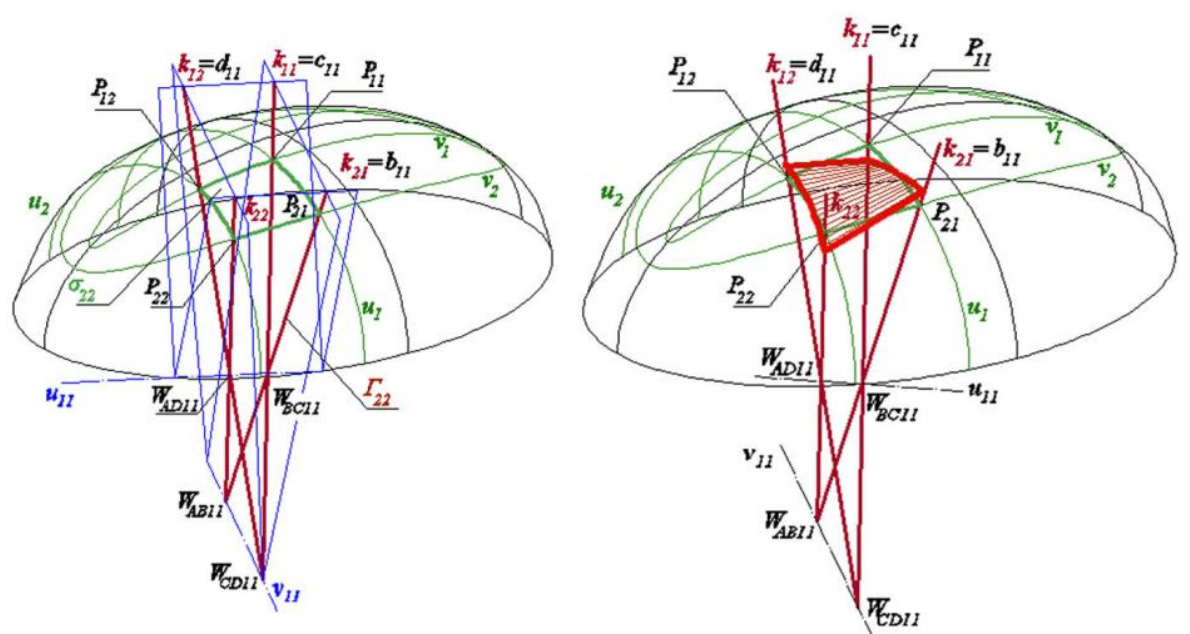

Fig. 4. The concept of the activities and objects taking into account during creating segments of a shell structure

Rys. 4. Koncepcja działań i obiektów biorących udział w wyznaczaniu segmentów pewnej struktury powłokowej 
The directrices $e_{i, j}, f_{i, j}$ of each segment $\Omega_{i, j}$ are fixed on two opposite planes of the same controlling composition so that their ends would belong to the side edges as well as the restrictions connected with the material properties of free deformed folded sheets would be satisfied.

To summarize, the main aim of the presented way is to obtain such building objects which are characterized by: a) integrated shapes and position of the segments of their shell structure and walls, b) effective arrangement of the segments by means of the base surface and the straight lines and planes normal to it in chosen points so that the areas of the sectors $\sigma_{i, j}$ would be close to the areas of the segments $\Omega_{i, j}$ as accurate as possile.

\section{Shaping of forms of the shell structures with the typical ways}

The activities required by the way and leading to form a mode of a shell structure are described below on the example of a base ellipsoid $\sigma$ whose mathematic representation is given by:

$$
\frac{x^{2}}{a^{2}}+\frac{y^{2}}{b^{2}}+\frac{z^{2}}{c^{2}}=1
$$

where: $a=24000 \mathrm{~mm}, b=18000 \mathrm{~mm}, c=11000 \mathrm{~mm}, x, y, z$-variables.

The curves $t_{i}$ and $w_{j}$ and points $N_{i, j}$ (for $i, j=1,2$ ) resulting from a division of the geometrical surface $\sigma$ into the sectors $\sigma_{i, j}$ by means of two sets of planes parallel to the axis $z$ [10-12] so that, any plane of one set intersects the planes of the other set at the right angles are determined in the typical solutions (Fig. 5) [2, 13] concerning geometrical forms of the shell structures. Such an action enables us to obtain an orthogonal projection of planar lines of the intersection of this surface by the above planes onto a horizontal plane in the shape of a planar orthogonal networks [12, 14].

Constructions of these lines can be started with fixing the ellipses $w_{0}$ and $t_{0}$ contained in the planes $(y, z)$ and $(x, z)$ of the local coordinate system of the ellipsoid $\sigma$. The vertex $N_{0,0}$ of $\sigma$ was constructed as the point of intersecting of the above lines. The points $N_{1,0}$ and $N_{2,0}$ were delimited on the line $w_{0}$ as well as the points $N_{0,1}$ i $N_{0,2}$ were fixed on the line $t_{0}$ in a constant arrangement equal to $R_{o}=$ $6500 \mathrm{~mm}$.

For the purpose of constructing other points $N_{i, j}$ (for $i=1,2$ and $j=1,2$ ) there were led two sets of planes $\left\{\xi_{i t}\right\}$ and $\left\{\xi_{w j}\right\}$ passing through the above points and parallel either to the plane $(y, z)$ or to the plane $(x, z)$. The above planes intersect the ellipsoid $\sigma$ in ellipses $t_{i}$ and $w_{j}$ expressed as: 


$$
\left.\begin{array}{l}
x=a_{t i} \cdot \cos \left(\tau_{i}\right) \\
y=y N_{i, 0} \\
z=c_{t i} \cdot \sin \left(\tau_{i}\right)
\end{array}\right\}
$$

where: $a_{t i}=a \cdot \sqrt{1-\frac{y N_{i, 0}^{2}}{b^{2}}}, c_{t i}=c \cdot \sqrt{1-\frac{y N_{i, 0}^{2}}{b^{2}}}, \tau_{1}-$ the angular coefficient,

and

$$
\left.\begin{array}{l}
x=x N_{0, j} \\
y=b_{w j} \cdot \cos \left(\omega_{j}\right) \\
z=c_{w j} \cdot \sin \left(\omega_{j}\right)
\end{array}\right\}
$$

where: $b_{w j}=b \cdot \sqrt{1-\frac{x N_{0, j}^{2}}{a^{2}}}, c=c \cdot \sqrt{1-\frac{x N_{0, j}^{2}}{a^{2}}}, \omega_{j}-$ the angular coefficient, $x$, $y, z$ - variables.
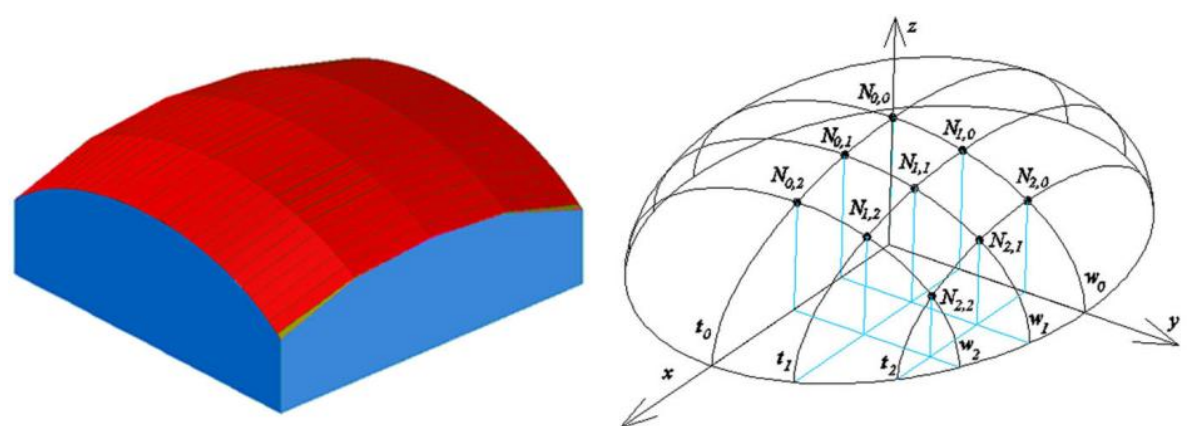

Fig. 5. The points and lines accepted on the base ellipsoid $\sigma$ and visualization of the shell structure based on this ellipsoid

Rys. 5. Punkty i linie przyjęte na elipsoidzie bazowej $\sigma$ oraz wizualizacja struktury powłokowej powstałej na podstawie tej elipsoidy

The points $N_{i, j}$ were obtained as the points of intersecting the ellipsoid $\sigma$ with the edges of the intersection of the proper pairs of the above planes. Their coordinates are presented in Tab. 1.

Next, the sections $N_{0,0} N_{2,0}$ and $N_{0,1} N_{2,1}$ of ellipses $w_{0}$ and $w_{1}$ were accepted as the directrices of the sector $\sigma_{w j}(j=1)$ of a ruled surface approximating a suitable strip of the ellipsoid $\sigma$. The sector $\sigma_{w j}$ is accepted as the geometrical model 
of the neutral surface of the shell structure strip $\Sigma_{w j}$. However, the sections $N_{0,1} N_{2,1}$ and $N_{0,2} N_{2,2}$ of the ellipses $w_{1}, w_{2}$ were accepted as the directrices of the sector $\Sigma_{w 2}$ of other ruled surface modeling the second strip of the designed shell structure. In addition, arrangements of rulings of two above stripes have to satisfy the structural condition assuring the freedom of the transversal width increments of all shell folds [8]. There were calculated the values of the coordinates of the ruling ends of the above stripes by means of the computer program which was written on the base of the Reichhart's algorithm [6].

Table 1. The coordinates of the chosen points $N_{i, j}$ on the base ellipsoid $\sigma$

Tabela 1. Współrzędne punktów $N_{i, j}$ wybranych na elipsoidzie bazowej $\sigma$

\begin{tabular}{|c|c|c|c|}
\hline Point & $\boldsymbol{x}[\mathbf{m m}]$ & $\boldsymbol{y}[\mathbf{m m}]$ & $\boldsymbol{z}[\mathbf{m m}]$ \\
\hline$N_{0,0}$ & 0.00000 & 0.00000 & 11000 \\
\hline$N_{1,0}$ & 0.00000 & 6459.0 & 10267 \\
\hline$N_{2,0}$ & 0.00000 & 12515 & 7906.0 \\
\hline$N_{0,1}$ & 6487.0 & 0.00000 & 10590 \\
\hline$N_{0,2}$ & 12855 & 0.00000 & 9289.0 \\
\hline$N_{1,1}$ & 6487.0 & 6459.0 & 9828.0 \\
\hline$N_{2,1}$ & 6487.0 & 12515 & 7326.0 \\
\hline$N_{1,2}$ & 12855 & 6459.0 & 8409.0 \\
\hline$N_{2,2}$ & 12855 & 12515 & 5272.0 \\
\hline
\end{tabular}

The obtained model of one of four symmetrical parts of the shell structure is presented in Fig. 6. It is composed of two stripes formed by 18 shell sheets and characterized by a relatively big roof area non-performed by folded sheets along the longitudinal border $N_{2,0} N_{2,2}$.
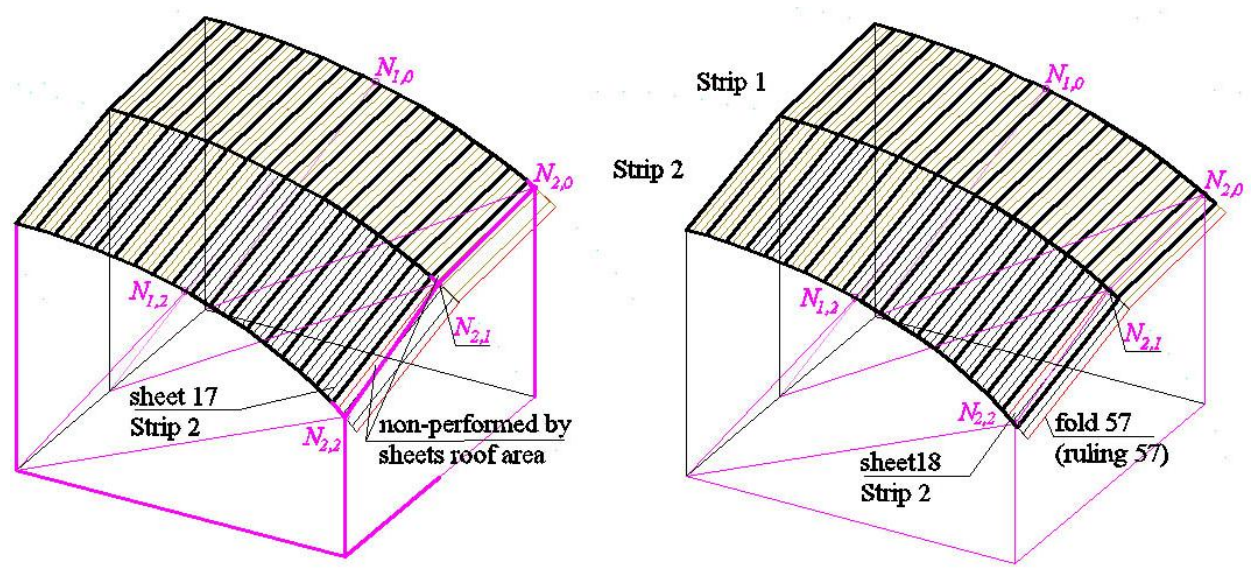

Fig. 6. The edge model of a building object covered with a strip shell structure

Rys. 6. Model krawędziowy pewnego obiektu budowlanego przykrytego powłoką strukturą pasmową 


\section{Shaping of integrated shell structures forms with an innovative way}

The author's new way of shaping effective thin-walled shell structures is based on creating polyhedral controlling structures whose edges and sides are either contained in straight lines and planes normal to a base surface or close to these ones.

The main characteristic figure of this way is the fact that the properties of the accepted base surface influence on the controlling structure deciding about a general form of a shell structure. This makes that the presented method is much more intuitive as well as enables us to create the controlling structures as integrated with flat or shell walls and windows of building objects due to a possibility of diversification of shell structures shapes. If we keep the above recommendation, then we will able to shape free, original and real attractive shell structure forms.

Thus, the way recommends us this the constructions which are presented bellow. They are considered on the example of the known base ellipsoid $\sigma$ expressed by (1).

At the beginning, we accept that the gable walls are inclined to the vertical direction, which is similar to the axis $z$ of the local coordinate system of $\sigma$, at the angle different from zero. This inclination is dependent on the directions of the normal straight lines $n_{i, j}$ of $\sigma$ at the before accepted points $N_{i, j}$ of the intersection of the ellipses $t_{i}$ and $w_{j}$ (for $\left.i, j=0,1,2\right)$, see Fig. 7 .
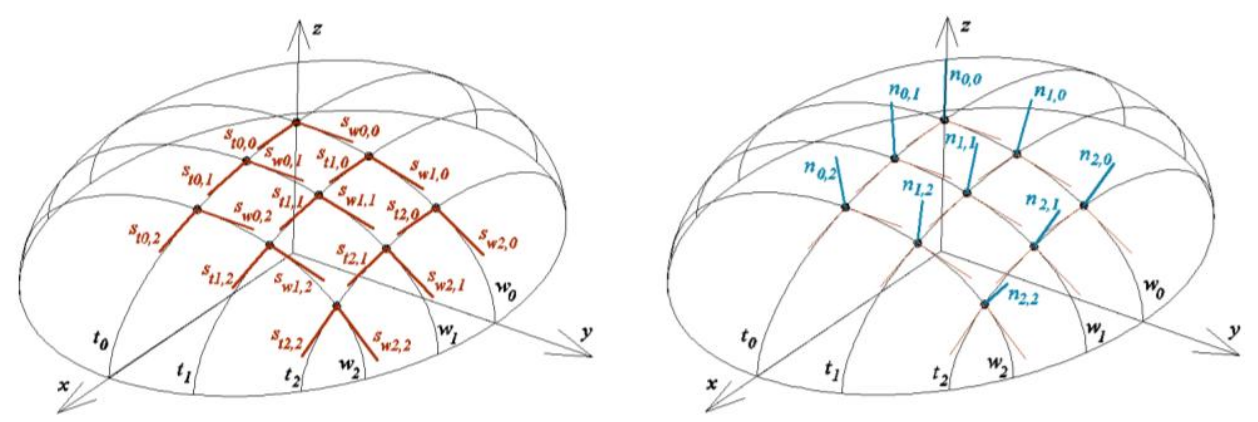

Fig. 7. The straight lines $s_{t i, j}, s_{w i, j}$ and $n_{i, j}$ tangent and normal to the ellipsoid $\sigma$ at the points $N_{i, j}$

Rys. 7. Proste $s_{t i, j}, s_{w i, j}$ i $n_{i, j}$ styczne i normalne do bazowej elipsoidy $\sigma$ w punktach $N_{i, j}$

To this end, the components of the direction vectors $\vec{S}_{t i, j}, \vec{S}_{w i, j}$ of the straight lines $s_{t i, j}, s_{w i, j}$ tangent to the ellipses $t_{i}$ and $w_{j}$ at the points $N_{i, j}$ (as well as the ellipsoid $\sigma$ ) were constructed by using two bellow parametric equations expressed as: 


$$
\vec{s}_{t i, j}=\left[l_{S t i, j}, m_{S t i, j}, n_{S t i, j}\right]
$$

where: $l_{S t i, j}=-a_{t i} \cdot \sin \left(\tau_{i}\right), m_{S t i, j}=0.0000, n_{S t i, j}=c_{t i} \cdot \cos \left(\tau_{i}\right)$,

$$
\tau_{i} \text { - variable }
$$

and

$$
\vec{s}_{w i, j}=\left[l_{S w i, j}, m_{S w i, j}, n_{S w i, j}\right]
$$

where: $l_{S w i, j}=0.0000, m_{S w i, j}=-b_{w j} \cdot \sin \left(\omega_{j}\right), n_{S w i, j}=c_{w j} \cdot \cos \left(\omega_{j}\right)$,

$\omega_{j}-$ variable.

The values of the components of the direction vectors $\vec{S}_{t i, j}, \vec{S}_{w i, j}$ of the straight lines $s_{t i, j}, s_{w i, j}$ being characterized by the identical lengths equal to 5000.0 $\mathrm{m}$ are presented in Tabs. 2, 3. The values of the angles $\tau_{i}{ }^{*}, \omega_{j}{ }^{*}$ of the inclination of the straight line $n_{i, j}$ to the local axis $x_{L i}$ of the ellipse $t_{i}$ (the axis $y_{L i}$ of the ellipse $w_{j}$ ) calculated for the point $N_{i, j}$ are also given in these tables and they are different from the coefficients $\tau_{i}, \omega_{j}$.

Next, the components of the directed vector $\vec{n}_{i, j}=\left[l_{n i, j}, m_{n i, j}, n_{n i, j}\right]$ of the straight line $n_{i, j}$ normal to the ellipsoid $\sigma$ in the point $N_{i, j}$ (see Fig. 7) presented in Tab. 4 were obtained by using the formula expressed as

$$
\vec{n}_{i, j}=\vec{s}_{t i, j} \times \vec{s}_{w i, j}
$$

Table 2. The values of the components of the direction vector $\vec{S}_{t i, j}$ and the measure of the angle $\tau_{i}{ }^{*}$

\begin{tabular}{|c|c|c|c|c|}
\hline Tangent vector / Point & $l_{S t i, j}[\mathrm{~mm}]$ & $\boldsymbol{m}_{S t i, j}[\mathbf{m m}]$ & $n_{S t i, j}[\mathrm{~mm}]$ & $\tau_{i}^{*}\left[{ }^{0}\right]$ \\
\hline$N_{0,0}$ & 5000.0 & 0.0000 & 0.0000 & 90.000 \\
\hline$N_{1,0}$ & 5000.0 & 0.0000 & 0.0000 & 90.000 \\
\hline$N_{2.0}$ & 5000.0 & 0.0000 & 0.0000 & 90.000 \\
\hline$N_{0,1}$ & 4959.1 & 0.0000 & -638.11 & 74.318 \\
\hline$N_{0,2}^{, 1}$ & 4801.2 & 0.0000 & -1395.8 & 57.612 \\
\hline$N_{1,1}$ & 4952.6 & 0.0000 & -686.7 & 73.167 \\
\hline$N_{2,1}$ & 4915.6 & 0.0000 & -914.38 & 67.910 \\
\hline$N_{1,2}$ & 4760.5 & 0.0000 & -1528.8 & 54.980 \\
\hline$N_{2,2}$ & 4450.1 & 0.0000 & -2279.5 & 41.821 \\
\hline
\end{tabular}
for the ellipse $t_{i}$ at the point $N_{i, j}$

Tabela 2. Wartości składowych wektora kierunkowego $\vec{S}_{t i, j}$ i wartości miar kąta $\tau_{i}$ dla elipsy $t_{i}$ w punkcie $N_{i, j}$ 
Table 3. The values of the components of the direction vector $\vec{S}_{w i, j}$ and the measure of the angle $\omega_{j}^{*}$ for the ellipse $\omega_{j}$ at the point $N_{i, j}$

Tabela 3. Wartości składowych wektora kierunkowego $\vec{S}_{t i, j}$ i miary kąta $\omega_{j}^{*}$ dla elipsy $\omega_{j}$ w punk$\operatorname{cie} N_{i, j}$

\begin{tabular}{|c|c|c|c|c|}
\hline Tangent vector / point & $\boldsymbol{l}_{\boldsymbol{S w i , j}, j}[\mathbf{m m}]$ & $\boldsymbol{m}_{\boldsymbol{S} \boldsymbol{w i}, \boldsymbol{j}}[\mathbf{m m}]$ & $\boldsymbol{n}_{\boldsymbol{S} \boldsymbol{w i}, \boldsymbol{j}}[\mathbf{m m}]$ & $\boldsymbol{\omega}_{\boldsymbol{j}}{ }^{{ }}\left[{ }^{\mathbf{0}}\right]$ \\
\hline$N_{0,0}$ & 5000.0 & 0.0000 & 90.000 & 90.000 \\
\hline$N_{1,0}$ & 4867.4 & -1143.4 & 90.000 & 68.972 \\
\hline$N_{2,0}$ & 4304.2 & -2544.3 & 90.000 & 45.952 \\
\hline$N_{0,1}$ & 5000.0 & 0.0000 & 74.318 & 90.000 \\
\hline$N_{0,2}$ & 5000.0 & 0.0000 & 57.612 & 90.000 \\
\hline$N_{1,1}$ & 4855.8 & -1191.7 & 73.167 & 68.118 \\
\hline$N_{2,1}$ & 4215.2 & -2689.1 & 67.910 & 43.768 \\
\hline$N_{1,2}$ & 4806.1 & -1378.6 & 54.980 & 64.855 \\
\hline$N_{2,2}$ & 3741.4 & -3316.8 & 41.821 & 34.580 \\
\hline
\end{tabular}

Table 4 . The values of the components of the direction vectors $\vec{n}_{N i, j}$ of the identical length equal to 5000.0 normal to the ellipsoid $\sigma$ and having their started points at $N_{i, j}$

Tabela 4. Wartości składowych wektorów kierunkowych $\vec{n}_{N i, j}$ o identycznej długości 5000.0 normalnych do elipsoidy $\sigma$ i mających punkty początkowe w $N_{i, j}$

\begin{tabular}{|c|c|c|c|}
\hline Normal vector / point & $\boldsymbol{l}_{\boldsymbol{n} \boldsymbol{i}, \boldsymbol{j}}[\mathbf{m m}]$ & $\boldsymbol{m}_{\boldsymbol{n}, \boldsymbol{j}}[\mathbf{m m}]$ & $\boldsymbol{n}_{\boldsymbol{n i}, \boldsymbol{j}}[\mathbf{m m}]$ \\
\hline$N_{0,0}$ & 0.0000 & 0.0000 & 5000.0 \\
\hline$N_{1,0}$ & 0.0000 & 1143.4 & 4867.5 \\
\hline$N_{2,0}$ & 0.0000 & 2544.3 & 4304.2 \\
\hline$N_{0,1}$ & 638.11 & 0.0000 & 4959.1 \\
\hline$N_{0,2}$ & 1395.8 & 0.0000 & 4801.2 \\
\hline$N_{1,1}$ & 667.31 & 1181.1 & 4812.4 \\
\hline$N_{2,1}$ & 774.62 & 2656.6 & 4164.4 \\
\hline$N_{1,2}$ & 1474.8 & 1317.3 & 4592.3 \\
\hline$N_{2,2}$ & 1789.5 & 3097.1 & 3493.6 \\
\hline
\end{tabular}

In the part, bellow, it is presented the application of the way in geometrical shaping of the shell structures being characterized by not very complicated geometrical form close to the base ellipsoid $\sigma$.

In the initial stage of the description we will consider the set $\left\{n_{0,2}, n_{1,2}, n_{2,2}\right.$, $\left.n_{1,2 s}, n_{2,2 s}\right\}$ of five straight lines, from among of which three $n_{0,2}, n_{1,2}, n_{2,2}$ are accepted as the straight lines $n_{i, j}$ normal to $\sigma$ distinguished in previous example and other two straight lines $n_{1,2 s}, n_{2,2 s}$ are lain symmetrically to the lines $n_{1,2}, n_{2,2}$ towards the plane $(x, z)$.

Such an action results from the fact, that these plane $(x, z)$ is the plane of symmetry of $\sigma$. Using this symmetry we may chose and examine the triad $\left\{n_{0,2}\right.$, $\left.n_{1,2}, n_{2,2}\right\}$ only in the further constructions. Because this triad is formed by skew 
straight lines and we want to get a flat gable wall, then we should to fix such a location of a plane $\zeta_{w N s c 2}$ of the gable wall in which the sum of square measures of the angles $\varphi_{n i, j}$ (for $i=0,1,2$ and $j=2$ ) of the inclination of the straight lines of the set $\left\{n_{0,2}, n_{1,2}, n_{2,2}, n_{1,2 s}, n_{2,2 s}\right\}$ to this plane would be as least as possible in the range of shaping accuracy, which is equal to $0.01^{\circ}$ in the bellow examples.

Using this symmetry, the author assumed that the values of the angles of the inclination of the lines $n_{1,2}, n_{2,2}$ to the planes $\zeta_{w N s c 2}$ have to be included two times in order to take into consideration the lines $n_{1,2 s}, n_{2,2 s}$ in the operational research process.

The optimization of the inclination of the plane $\zeta_{w N s c 2}$ to the set $\left\{n_{0,2}, n_{1,2}\right.$, $\left.n_{2,2}, n_{1,2 s}, n_{2,2 s}\right\}$ of straight lines is based on searching for such a position of the point $N_{s c 2}$ on a straight line parallel to the axis $x$ and passing through the point $N_{p 0,2}$ that the above requirement concerning the angles $\varphi_{n i, j}$ is executed. $N_{p 0,2}$ is the end of the section contained in the straight line $n_{0,2}$ normal to $\sigma$, see Fig. 8 .

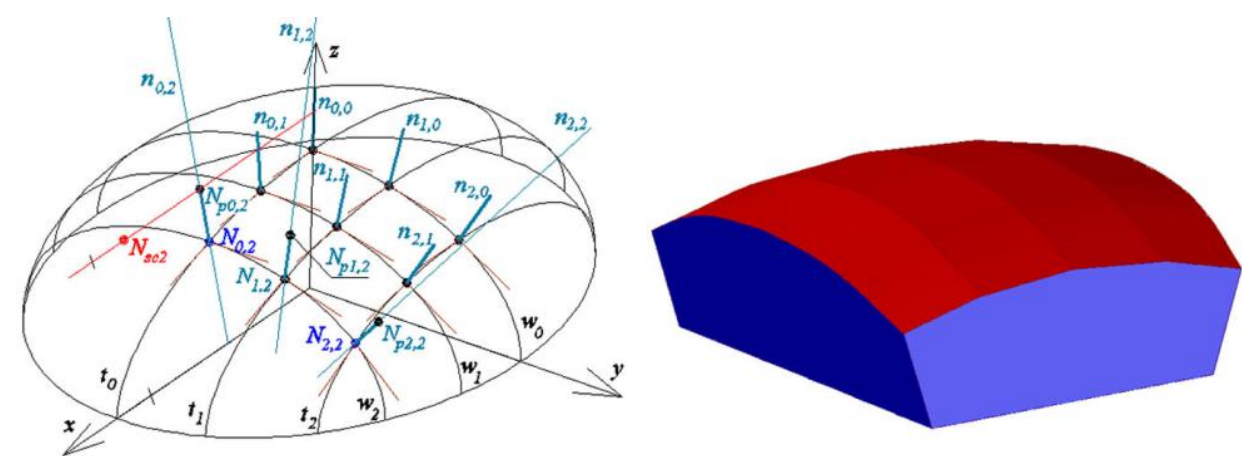

Fig. 8. The change of the inclination of the plane $\zeta_{w N s c 2}$ of the gable wall carried out with changing the position of the point $N_{s c 2}$ and the visualization of the final shells structure

Rys. 8. Zmiana pochylenia płaszczyzny $\zeta_{w N s c 2}$ ściany szczytowej przeprowadzona za pomocą zmiany położenia punktu $N_{s c 2}$ oraz wizualizacja wynikowej struktury powłokowej

The plane $\zeta_{w N s c 2}$ being sought passes through the point $N_{s c 2}, N_{0,2}$ as well as it is parallel to the axis $y$. Its equation is given by:

$$
A_{w j} \cdot x+B_{w j} \cdot y+C_{w j} \cdot z+D_{w j}=0 .
$$

The obtained results were used to create a geometrical model of a shell structure having oblique gable walls (Fig. 9). 

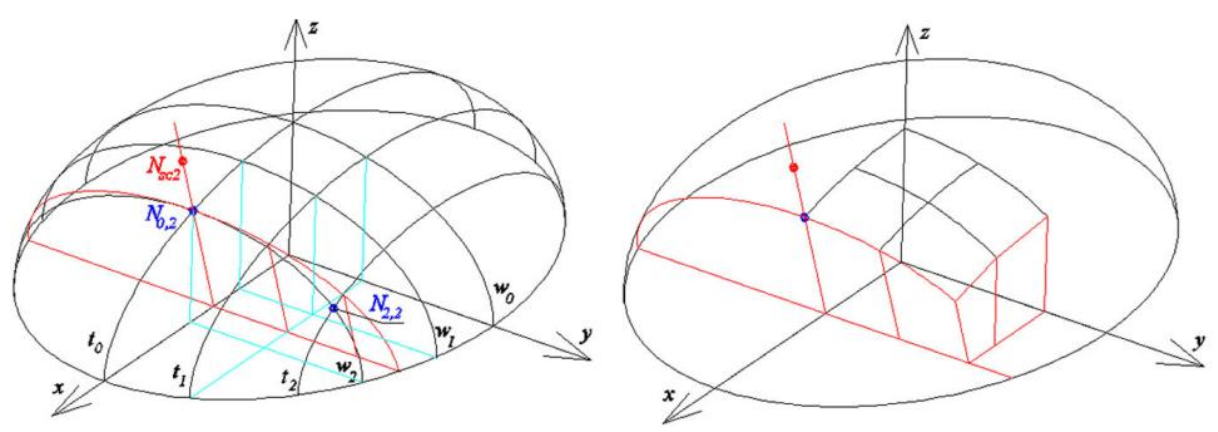

Fig. 9. Geometrical shaping of a structure having two slope gable walls

Rys. 9. Geometryczne kształtowanie struktury posiadającej dwie ukośne ściany szczytowe

The values of the parameters calculated while the operative research process of searching for the effective inclination of the plane $\zeta_{w N s c 2}$ to the straight lines $\left\{n_{0,2}, n_{1,2}, n_{2,2}\right\}$ are $t_{s c 2}=0.198, \varphi_{n 0,2}=2.15387^{\circ}, \varphi_{n 1,2}=\varphi_{n 1,2 s}=$ $=0.53967^{\circ}, \varphi_{n 2,2}=\varphi_{n 1,2 s}=6.86577^{\circ}, S_{\text {Min }}=56.999^{\circ 0}$. There were used the following denotations:

- $t_{s c 2}$ the parameter defining the distance between the points $N_{s c 2}$ and $N_{p 0,2}$,

- $\varphi_{n 0,2}, \varphi_{n 1,2}, \varphi_{n 2,2}, \varphi_{n 1,2 s}, \varphi_{n 2,2 s}$ - the angles of the inclination between the straight lines of the set $\left\{n_{0,2}, n_{1,2}, n_{2,2}, n_{1,2 s}, n_{2,2 s}\right\}$ and the plane $\zeta_{w N s c 2}$,

- $S_{M i n}$ - the minimized sum of the square measures of the above angles.

The coordinates of the used points $N_{p 0,2}, N_{s c 2}$ found while the operative process are presented in Tab. 5, 6. The point $N_{p 0,2}$ belongs to straight lines $n_{0,2}$ and its distance from the point $N_{0,2}$ is equal to $5000.0 \mathrm{~m}$.

Table 5. The values of the coordinates of the auxiliary points used in the operative research process

Tabela 5. Wartości współrzędnych pomocniczych punktów wykorzystanych w procesie optymalizacji

\begin{tabular}{|c|c|c|c|c|c|c|}
\hline Point & Coordinate & Value [mm] & Coordinate & Value [mm] & Coordinate & Value [mm] \\
\hline $\boldsymbol{N}_{s c \mathbf{2}}$ & $x_{N s c 2}$ & 14449.2 & $y_{N s c 2}$ & 0.0000 & $z_{N s c 2}$ & 14090.1 \\
\hline $\boldsymbol{N}_{p \mathbf{0 , 2}}$ & $x_{N p 0,2}$ & 14251.3 & $y_{N p 0,2}$ & 0.0000 & $z_{N p 0,2}$ & 14090.1 \\
\hline
\end{tabular}

As the result of the above operative research process, the following values of the coefficients of the plane $\zeta_{w N s c 2}$ were obtained: $A_{w j}=100.000 \mathrm{~mm}$, $B_{w j}=0.000 \mathrm{~mm}, C_{w j}=-33.1967 \mathrm{~mm}, D_{w j}=24000 \mathrm{~mm}$.

In the next stage of the way's description, we will only consider the triad of the straight lines $\left\{n_{0,2}, n_{1,2}, n_{2,2}\right\}$ normal to $\sigma$. From the before example we know that the above straight lines are skew. Now, we are going to get a gable wall, which is symmetrical toward the plane $(x, z)$, so it is composed of two symmetrical parts so that each of these parts would be flat. The points are going to have 
an rectilinear shared edge contained in the plane $(x, z)$ (see Fig. 10). In such a way we want to adopt the position of two planes of the folded gable wall to the above normal lines more precisely. Thus, the inclination of each of these two parts of the gable wall should be more accurate closer to direction of the proper triad $\left\{n_{0,2}, n_{1,2}, n_{2,2}\right\}$ or $\left\{n_{0,2}, n_{1,2 s}, n_{2,2 s}\right\}$ of straight lines than it was in previous example using one planar gable wall.

Therefore, the inclination of the plane of the gable wall is optimized in the first, basic stage of the activities leading to delimiting the above two symmetrical parts. However, in the second stage the location of this plane toward the points $N_{0,2}, N_{1,2}, N_{2,2}$ is optimized.

The above two stages were made independently. There were not used Thus, the optimization for two parameters: the inclination and the location of $\zeta_{w N s c 2}$ at the same time was not executed due to the greater significance of the inclination than the position as well as there are no circumstances to accept the suitable quotient of inclination and position weights.

The components of the normal vector to the plane $\zeta_{w N p p 2}$ are sought, so that, the sum of the square measures of the angles $\varphi_{n i, j}$ of the inclination of the straight lines $n_{0,2}, n_{1,2}, n_{2,2}$ to this plane would be as small as possible in the range of the accepted accuracy being equal to $0.01^{\circ}$.

The optimization of the inclination of the plane $\zeta_{w N p p 2}$ and the set $\left\{n_{0,2}, n_{1,2}\right.$, $\left.n_{2,2}\right\}$ consists in searching for such a position of the point $N_{p p 2}$ belonging to the straight line $N_{p 0,2}, N_{p 2,2}$, Fig. 10, that the above criterion would be performed. The obtained plane $\zeta_{w N p p 2}$ passes through the points $N_{p p 2}, N_{0,2}, N_{p 2,2}$.

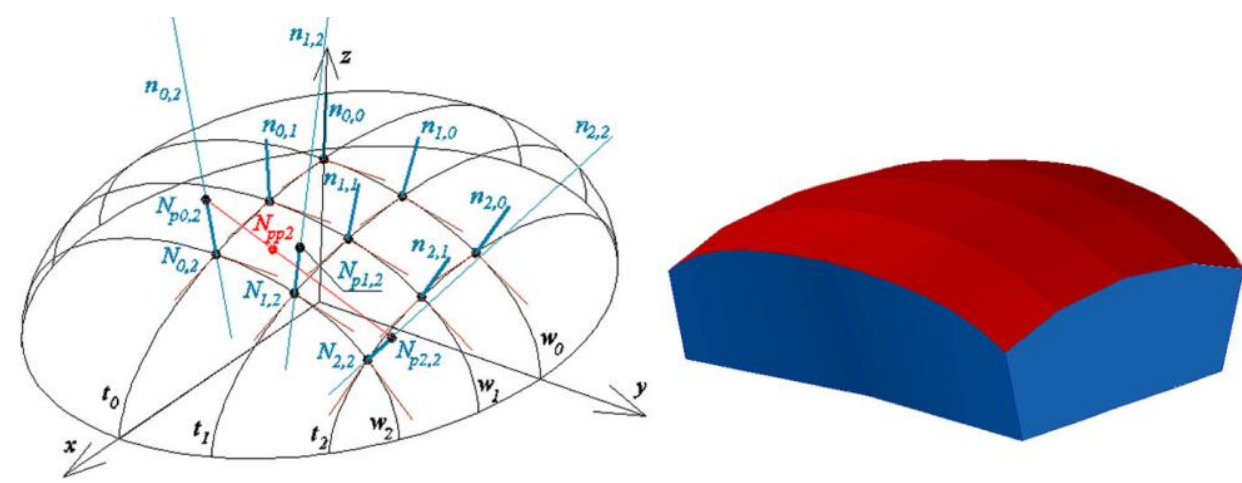

Fig. 10. The creation and visualization of a model of a shell structure having two oblique gable walls composed of two flat pieces symmetrical toward the plane $(x, z)$

Rys. 10. Tworzenie i wizualizacja pewnej struktury powłokowej, której każda z dwóch ukośnych ścian szczytowych składa się z dwóch części symetrycznych względem płaszczyzny $(x, z)$

The obtained results have been used to create a geometrical model of a shell structure being characterized by two oblique flat parts of the same gable wall 
(see Fig. 11) divided by the shared edge contained in the plane $(x, z)$ and passing through the point $N_{0,2}$.
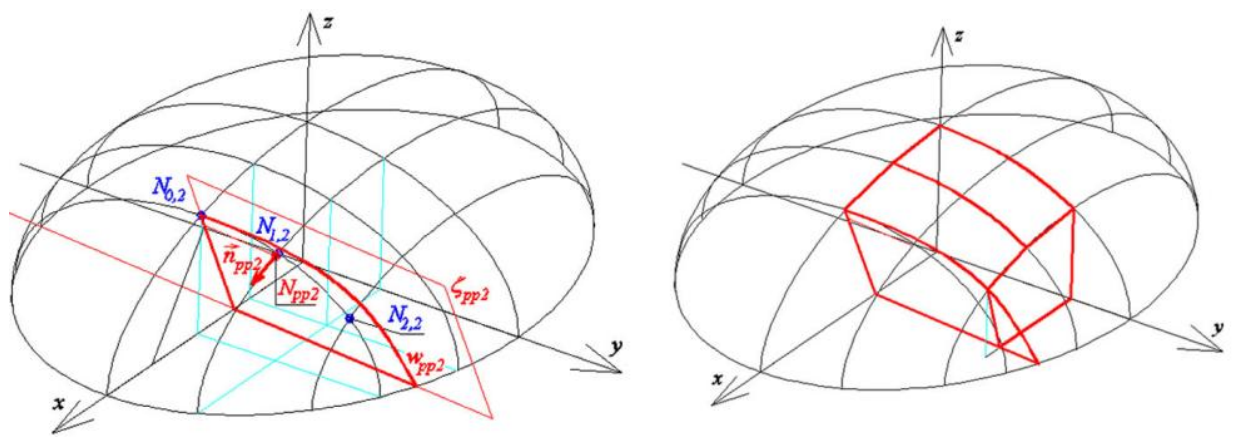

Fig. 11. The creation and visualization of a model of a shell structure having two oblique gable walls composed of two flat pieces symmetrical toward the plane $(x, z)$

Rys. 11. Tworzenie i wizualizacja pewnej struktury powłokowej, której każda z dwóch ukośnych ścian szczytowych składa się z dwóch części symetrycznych względem płaszczyzny $(x, z)$

The obtained values of the parameters used while optimizing the inclination of the plane $\zeta_{w N p p 2}$ to the set $\left\{n_{0,2}, n_{1,2}, n_{2,2}\right\}$ are $t_{p p 2}=0,328, \varphi_{n 0,2}=1.76297^{\circ}$, $\varphi_{n 1,2}=1.65881^{\circ}, \varphi_{n 2,2}=3.61376^{\circ}, S_{\operatorname{Min}}=18.91893^{\circ \mathrm{oo}}$. We use the same notation as in previous example. Additionally, $t_{p p 2}$ is the coefficient of the division of the section $N_{p 0,2} N_{p 2,2}$ by the point $N_{p p 2}$.

The coordinates of the points $N_{p p 2}, N_{p 2,2}$ are presented in Tab. 6 .

Table 6 . The values of the coordinates of the auxiliary points used in the operative research process

Tabela 6. Wartości współrzędnych pomocniczych punktów wykorzystanych w procesie optymalizacji

\begin{tabular}{|c|c|c|c|c|c|c|}
\hline Point & Coordinate & $\begin{array}{c}\text { Value } \\
{[\mathbf{m m}]}\end{array}$ & Coordinate & Value [mm] & Coordinate & $\begin{array}{c}\text { Value } \\
{[\mathbf{m m}]}\end{array}$ \\
\hline$N_{p p 2}$ & $x_{p p 2}$ & 14380.4 & $y_{p p 2}$ & 5120.6 & $z_{p p 2}$ & 12343.7 \\
\hline$N_{p 2,2}$ & $x_{N p 2,2}$ & 14645.0 & $y_{N p 2,2}$ & 15611.7 & $z_{N p 2,2}$ & 8765.7 \\
\hline
\end{tabular}

The values of the parameters used in the additional operative research process consisting in searching for the distance of the plane $\zeta_{\text {wNpp } 2}$ from the points $N_{0,2}, N_{1,2}, N_{2,2}$ are: $t_{N p 2}=0,2445, d_{N 0,2}=d_{N 2,2}=121.9 \mathrm{~m}, d_{N 1,2}=244.5 \mathrm{~m}$, $S_{\text {Min }}=89520.6 \mathrm{~m} \cdot \mathrm{m}$, where $t_{p p 2}$ is the parameter defining the distance between the plane $\zeta_{w N p p 2}$ and point $N_{1,2}$. The calculation accuracy is equal to $1 \mathrm{~mm}$.

Finally, the values of the coefficients of the plane $\zeta_{w N p p 2}$ are: $A_{w j}=1000.000, B_{w j}=-104.170, C_{w j}=-324.576, D_{w j}=-971164$. 
We can use an analogous way if we need find the optimal inclination of the planes $\zeta_{w 0}, \zeta_{w 1}$ to the other triad $\left\{n_{0, j}, n_{1, j}, n_{2, j}\right\}$, where: $j=1,2,3$, of straight lines normal to $\sigma$.

Regular patterns on the shell structures resulting from occurring the edges or areas of discontinuity between adjacent shell segments disturb smoothness or discontinuity of the shell structure. The shell structures can assume very attractive general forms and let us adopt designed objects to environmental conditions and functional requirements owing to these patterns. Similarly, the complication degree of the framework's shape increases $[3,15]$.

\section{Conclusions}

The presented way of geometrical shaping of the thin-walled steel shell structures lets us to obtain innovative shell forms similar to a initially accepted geometrical surfaces characterized by any sign of the Gaussian curvature, in spite of the restrictions connected with the shape changes of the flat folded sheets into shell forms while assembling to the directrices. These restrictions limits forms of the individual shells (segments) to sectors of the ruled surfaces characterized by the non-positive Gaussian curvature. The value of the shell curvature is dependent on the physical properties of the shell folds including their stiffness.

The rectilinear or curvilinear edges or flat areas between consecutive segments are specific characteristics of such structures because of the restrictions related with shape changes of the freely transformed sheets.

The integration of the components (flat walls, roof, shells and their edges) of a designed object as well as the effective covering the basic surface area with segments are the main advantage of the method.

If we want to obtain a controlling structure whose edges and faces are more and more close to straight lines and planes normal to the base ellipsoid, then we will have to create more and more locally extended forms of a shell structure as well as the whole building object including flat, elevation walls, windows.

\section{References}

[1] Abramczyk J.: Specificity of shaping light gauge steel shells. Proc. of II Intern. Conf. „Structures and Architecture”, Guimaraes, Portugal 2013, CD .

[2] Abramczyk J.: Nowe możliwości kształtowania formy przekrycia powłokowego wykonanego z blach trapezowych. Mat. 58. Konferencji Naukowej Komitetu Inżynierii Lądowej Wodnej PAN oraz Komitetu Nauki PZITB, Rzeszów-Krynica 2012.

[3] Abramczyk J.: Multi-segment shell structures. Lightweight Structures in Civil Engineering. Proc. of XVIII Intern. Sem. of IASS Polish Chapter, MICROPUBLISHER-C-P, Jan B. Obrębski (ed.), Warszawa 2012, pp. 38-47.

[4] Abramczyk J.: Powłokowe formy architektoniczne z blach fałdowych. Mat. symp. z cyklu „Nowe osiagnnięcia nauki i techniki w budownictwie: Projektowanie kon- 
cepcyjne - kształtowanie konstrukcji, konstrukcje z blach fałdowych, konstrukcje cięgnowe”. Oficyna Wydawnicza Politechniki Rzeszowskiej, Rzeszów 2000, s. 65-72.

[5] Abramczyk J.: Free forms of light gauge steel shell structures. Lightweight Structures in Civil Engineering. Proc. of XVIII Intern. Sem. of IASS Polish Chapter, MICRO-PUBLISHER-C-P, Jan B. Obrębski (ed.), Warszawa 2012, pp. 48-53.

[6] Reichhart A.: Geometrical and structural shaping of shells made of profiled metal sheets (monograph in polish). Oficyna Wydawnicza Politechniki Rzeszowskiej, Rzeszów 2002.

[7] Abramczyk J.: Peculiar properties of ruled surfaces useful in shaping light gauge steel shells. Beyond the Limits of Man. Proc. of IASS 2013 Symposium, Wrocław, Poland 2013, pp. 1424-1432.

[8] Abramczyk J.: Wpływ kształtu płaskich arkuszy i konstrukcji podpierających zakrzywione przekrycia z blach fałdowych na ich postać geometryczną, doctoral thesis. Rzeszów 2011.

[9] Reichhart A.: Powłokowe formy architektoniczne z blach fałdowych. Mat. Symp. z cyklu „Nowe osiagnięcia nauki i techniki w budownictwie: Projektowanie koncepcyjne - kształtowanie konstrukcji, konstrukcje z blach fałdowych, konstrukcje cięgnowe”. Oficyna Wydawnicza Politechniki Rzeszowskiej, Rzeszów 2000, s. $65-72$.

[10] Biegus A.: Nośność graniczna zginanych i ściskanych blach fałdowych. Mat. symp. z cyklu ,Nowe osiagnnięcia nauki i techniki w budownictwie: Blachy fałdowe - zastosowania i rozwiązania”, Rzeszów 1995.

[11] Bródka J., Garncarek R., Miłaczewski K.: Blachy fałdowe w budownictwie stalowym. Arkady, Warszawa 1984.

[12] Davies J.M., Bryan E.R.: Manual of stressed skin diaphragm design. Granada, London 1982.

[13] Wei-Wen Y.: Cold-formed steel design. John Wiley \& Sons, Canada 2000.

[14] Gioncu V., Petcu D.: Corrugated hypar structures. Proc. of Inter. Conf. LSCE, Warsaw 1995, pp. 637-644.

[15] Obrębski J.B.: UNIDOM - Space bar system. Lightweight Structures in Civil Engineering. Proc. of XII Intern. Sem. of IASS Polish Chapter, MICROPUBLISHER-C-P, Jan B. Obrębski (ed.). Warsaw 2006, pp. 76-87.

\title{
PODSTAWY GEOMETRYCZNEGO KSZTALTOWANIA EFEKTYWNYCH FORM STRUKTUR POWLOKOWYCH
}

\author{
Streszczenie
}

Praca dotyczy geometrycznego kształtowania struktur powłokowych złożonych z pojedynczych powłok rozłożonych $\mathrm{w}$ efektywny sposób w przestrzeni, to jest w sposób zgodny $\mathrm{z}$ właściwościami regularnej powierzchni geometrycznej i z wykorzystaniem prostych i płaszczyzn normalnych do tej powierzchni. Pojedyncze segmenty są wykonane z przekształcanych do postaci powłokowej płaskich arkuszy jednokierunkowo pofałdowanej blachy fałdowej. Podczas przekształcania arkusze posiadają swobodę odkształceń poprzecznych, co zapewnia ich możliwie małe wytężenie - efektywną deformację materiału przeznaczonego do przenoszenia obciążeń użytkowych, ale co jednocześnie powoduje ograniczenia dotyczące ich powłokowej postaci. Ograniczenia te polegają na tym, że postać pojedynczego segmentu jest zbliżona do powierzchni pro- 
stokreślnej o niedodatniej krzywiźnie Gaussa, a postać fałdy do wycinka środkowego paraboloidy prostoliniowej prostej. Te ograniczenia zmian postaciowych fałd segmentów wywołane ich ściśle określonymi charakterystykami sztywnościowymi skutkują pojawieniem się krawędzi lub nieciągłości pomiędzy sąsiednimi segmentami w strukturze, które z jednej strony powodują konieczność projektowania dość specyficznych układów konstrukcyjnych podpierających, z drugiej zaś strony zwiększają możliwą rozpiętość $\mathrm{w}$ dwóch ortogonalnych kierunkach oraz atrakcyjność wizualną struktury w wyniku pojawienia się na jej powierzchni regularnych wzorów.

W pracy zaprezentowano sposób uzyskiwania dużej różnorodności, efektywnych, złożonych form powłokowych o ogólnej postaci zbliżonych do powierzchni geometrycznej o dowolnym znaku krzywizny Gaussa. Innowacyjność sposobu polega na zintegrowaniu formy całego obiektu budowlanego (ścian oraz dachu powłokowego), które osiaga się przez podział ścian elewacyjnych na płaskie obszary zawarte w płaszczyznach zbliżonych do płaszczyzn normalnych do zakładanej na wstępie powierzchni bazowej.

Opisane zagadnienia stanowią podstawę do opracowania metody kształtowania rozpatrywanych, efektywnych cienkościennych struktur powłokowych oraz dalszej wzajemnej integracji elementów obiektu budowlanego.

Słowa kluczowe: struktury powłokowe, powłoki z blach fałdowych, deformacja wstępna arkuszy fałdowych

Przestano do redakcji: $10.03 .2014 r$.

Przyjęto do druku: 02.06.2014 r.

DOI:10.7862/rb.2014.1 